\title{
Assessment of the effects of wastewater treatment plant effluents on receiving streams using oligochaete communities of the porous matrix
}

\author{
Régis Vivien ${ }^{1, *}$, Michel Lafont ${ }^{2}$, Inge Werner ${ }^{1}$, Mélanie Laluc ${ }^{3}$ and Benoit J.D. Ferrari ${ }^{1}$ \\ ${ }^{1}$ Swiss Centre for Applied Ecotoxicology (Ecotox Centre Eawag-EPFL), 1015 Lausanne, Switzerland \\ ${ }^{2}$ Laboratoire d'Ecologie des Hydrosystèmes Naturels et Anthropisés, Université Lyon I, 69622 Villeurbanne, France \\ ${ }^{3}$ GINGER/BURGEAP - Agence de Lyon, 19 rue de la Villette, 69425 Lyon Cedex 03, France
}

\begin{abstract}
Human activities can disturb the natural dynamics of exchanges between surface water and groundwater in rivers. Such exchanges contribute to the self-purification of the environment and an excess of infiltration can lead to contamination of groundwater. In addition, the porous matrix (coarse surface sediments and hyporheic zone), through which water exchanges occur, is a sink for pollutants. For environmental monitoring programs, it is therefore essential to take into account both the dynamics of vertical hydrological exchanges and the biological quality of this matrix. The functional trait (FTR) method, which is based on the study of oligochaete communities in coarse surface sediments and the hyporheic zone, was proposed as a tool to simultaneously assess the dynamics of vertical hydrological exchanges and the effects of pollutants present in the porous matrix. Here, we applied this method during two different periods (in March and September 2016), upstream and downstream of locations affected by discharges from wastewater treatment plants (WWTP) located in Switzerland. The biological quality of surface sediments and the hyporheic zone was shown to be better upstream of the WWTP in both campaigns. In addition, results suggested that the capacity for self-purification was lower downstream of the WWTP, and that groundwater at these locations was vulnerable to pollution by surface water. The FTR method proved valuable as a field method for detecting the effects of point source contamination on receiving streams. In the near future, this community-based approach will benefit from advances in the use of DNA barcodes for oligochaete species identification.
\end{abstract}

\begin{abstract}
Keywords: annelids / bioindication / porous matrix / stream functioning / contamination
Résumé - Évaluation des effets des rejets de stations d'épuration des eaux usées sur des cours d'eau récepteurs à l'aide de l'étude des communautés d'oligochètes du milieu poreux. Les activités humaines peuvent perturber la dynamique naturelle des échanges entre les eaux de surface et les eaux souterraines dans les cours d'eau. De tels échanges contribuent à l'autoépuration du cours d'eau et un excès d'infiltrations peut conduire à la contamination des eaux souterraines. De plus, le milieu poreux (sédiments grossiers superficiels et zone hyporhéique), à travers lequel se produisent les échanges hydrologiques, a la propriété de stocker les polluants. Il est donc essentiel de prendre en compte la dynamique des échanges hydrologiques verticaux et la qualité biologique du milieu poreux dans le cadre des programmes de surveillance de la qualité des cours d'eau. La méthode des traits fonctionnels (TRF), basée sur l'étude des communautés d'oligochètes des sédiments grossiers superficiels et de la zone hyporhéique, a été proposée comme outil permettant d'évaluer simultanément la dynamique des échanges hydrologiques verticaux et les effets des polluants présents dans le milieu poreux. Dans la présente étude, cette méthode a été appliquée lors de deux périodes différentes (mars et septembre 2016) en amont et en aval de sites affectés par les rejets de stations d'épuration des eaux usées (STEP) situées en Suisse. Une meilleure qualité biologique a été observée en amont des STEP lors des deux campagnes. De plus, les résultats ont suggéré que la capacité d'autoépuration du milieu était inférieure au niveau des sites situés en aval des STEP et qu'au niveau de ces sites les eaux souterraines étaient vulnérables aux pollutions des eaux de surface. La méthode TRF s'est
\end{abstract}

\footnotetext{
${ }^{*}$ Corresponding author: regis.vivien@centreecotox.ch
} 
avérée appropriée pour détecter les effets globaux de sources ponctuelles de contamination sur des cours d'eau récepteurs. Dans un futur proche, cette méthode bénéficiera des avancées de la recherche en cours sur l'utilisation de codes-barres génétiques pour l'identification des espèces d'oligochètes.

Mots clés : annélides / bioindication / matrice poreuse / fonctionnement des cours d'eau / contamination

\section{Introduction}

It is well recognized that human activities negatively impact watercourse ecosystems in four different ways: reduction of the connectivity between surface water and groundwater, modification of hydrological exchange processes, contamination of surface water and groundwater and reduction of habitat diversity. Such impacts can affect the biodiversity as it is strongly influenced by the interactions between the dynamics of vertical hydrological exchanges, the geomorphic context and the inputs of chemical substances (i.e. nutrients and pollutants) (Lafont, 2001; 2011; Lafont et al., 2010a; 2012; Schmitt et al., 2011; 2016).

The porous matrix, comprising the coarse surface sediments and hyporheic zone, constitutes an important habitat, and acts as a biological, chemical and physical filter of the water that travels through it. The filtering function is stimulated by the dynamics of water exchanges between surface water and groundwater (Hynes, 1983; Brunke and Gonser, 1997; Boulton, 2000; Jones and Mulholland, 2000; Hancock, 2002; Hancock and Boulton, 2005; Boulton and Hancock, 2006; Malard et al., 2006; Boulton, 2007; Breil et al., 2007). Indeed, active hydrological exchanges allow to supply the porous matrix with oxygen and therefore to stimulate degradation of organic matter by aerobic microbial and faunal activity (Hancock, 2002). In addition, exfiltration of good quality groundwater can lead to an improvement of the porous matrix and surface water quality. The self-purification potential of a watercourse is therefore controlled by these processes. When the infiltration of surface water into groundwater dominates, contaminants present in surface water can pollute the hyporheos and groundwater, which may lead to impairment of ecosystem function. Similarly, polluted groundwater exfiltration may lead to a degradation of surface water quality (Lafont et al., 2006). The dynamics of infiltration and exfiltration may be disturbed by anthropogenic activities (Lafont and Vivier, 2006; Breil et al., 2007; Lafont et al., 2010a). Infiltration of surface water into groundwater can be caused, for example, by a lowering of the groundwater table by excessive pumping, high discharges from combined sewer overflows, sudden water releases from reservoirs, or flash floods associated with an increase in impervious surfaces in the catchment area of a stream. The importance of taking into account surface water/groundwater exchanges for achieving a complete and robust evaluation of the ecological integrity of a watercourse has been emphasized for decades (Hynes, 1983).

The dynamics of the vertical hydrological exchanges and the specific quality of the porous matrix are generally not assessed in current monitoring programs of environmental water quality. While biotic indices based on invertebrate, oligochaete (in fine/sandy sediments), macrophyte and diatom communities (AFNOR, 2004; 2014; 2016a; b; OFEV, 2007; 2010) are widely accepted and applied, they only provide information on surface habitats. Nonetheless, restoration strategies aiming to improve the ecological status of streams need to consider and understand the functioning of streams, i.e. the interactions between the dynamics of vertical hydrological exchanges, the geomorphic context and the input of chemicals, as well as integrate knowledge of the biological quality of all compartments (Lafont, 2001).

Because oligochaetes are dominant in the interstices of the porous matrix and comprise species with a wide range of pollution tolerance, as well as species characteristic of surface sediments or groundwater, community assessments of this organism group provides important information on the functioning of a watercourse (Lafont et al., 2006). The oligochaete functional traits (FTR) method, which is focused on characterizing oligochaete communities of the porous matrix, can simultaneously assess the biological quality of the porous matrix and the dynamics of the hydrological exchanges between surface water and groundwater (Vivier, 2006; Lafont et al., 2006; 2010a). Several studies undertaken in France and Switzerland showed that this approach was suitable to distinguish between preserved and anthropogenically altered sites (Lafont et al., 2010a; Vivien et al., 2015).

In this study, we applied the FTR method for detecting the effects of WWTP effluents on the biological quality and the functioning of the receiving streams. We used this method during two periods of the year (in March and September 2016) upstream and downstream of two WWTP whose discharges significantly increased concentrations of pollutants at the downstream locations. The applicability of this approach is discussed and the prospects for future development are presented.

\section{Material and methods}

\subsection{Sites}

Wastewater treatment plant located in Hochdorf and in Buttisholz (Canton of Lucerne, Switzerland) were selected as study sites based on previous studies conducted in 2013 and 2014, which showed that the effluents of these WWTP substantially increased the load and concentrations of micropollutants at downstream locations (Munz et al., 2017; Tlili et al., 2017). In these two studies, a large number of pollutants was measured, as well as water quality parameters such as dissolved organic carbon, dissolved nitrogen and orthophosphates. The sampling locations upstream and downstream of the WWTP were the same as in Tlili et al. (2017), and a map showing the locations of these sites is provided by Tlili et al. (2017). The coordinates of the upstream and downstream locations of the WWTP of Hochdorf (Ron river) are $47.17462^{\circ} \mathrm{N} \quad 8.27986^{\circ} \mathrm{E}$ (downstream) and $47.173540^{\circ} \mathrm{N}$ $8.280462^{\circ} \mathrm{E}$ (upstream); the coordinates of the sites upstream and downstream of the WWTP of Buttisholz (Tannebach river) are $47.115241^{\circ} \mathrm{N} 8.071179^{\circ} \mathrm{E}$ (downstream) and $47.114089^{\circ} \mathrm{N}$ $8.074437^{\circ} \mathrm{E}$ (upstream). The downstream sampling locations 
Table 1. Overview and definition of functional traits (FTR1 to FTR4, FTRi) in coarse surface sediments and the hyporheic zone, with examples of characteristic oligochaete taxa.

\begin{tabular}{ll}
\hline Functional traits FTRs & Examples of characteristic taxa \\
\hline $\begin{array}{l}\text { FTR1: Includes active exchange describer (AED) } \\
\text { species, i.e. species indicating active hydrologic } \\
\text { exchanges between surface waters and groundwater }\end{array}$ & $\begin{array}{l}\text { All Lumbriculidae (Trichodrilus spp., Stylodrilus spp., etc.) } \\
\text { except Lumbriculus variegatus, Haber spp., Pristina spp., } \\
\text { Cernosvitoviella } \text { spp., Achaeta spp., Marionina argentea, } \\
\text { Haplotaxis gordioides, Propappus volki, Chaetogaster parvus }\end{array}$ \\
$\begin{array}{l}\text { FTR2: Includes oligochaete species which are } \\
\text { intolerant to chemical pollution }\end{array}$ & $\begin{array}{l}\text { Cernosvitoviella } \text { spp., Marionina argentea, Eiseniella tetraedra, } \\
\text { Nais alpina, Vejdovskyella comata, Stylodrilus heringianus, }\end{array}$ \\
$\begin{array}{l}\text { FThacodrilus falciformis, Propappus volki, Haplotaxis gordioides } \\
\text { tolerant to chemical pollution }\end{array}$ & $\begin{array}{l}\text { Nais elinguis, Pristina jenkinae, Dero digitata, Globulidrilus riparius, } \\
\text { Lumbriculus variegatus }\end{array}$ \\
$\begin{array}{l}\text { FTR4: Includes oligochaete species which indicate } \\
\text { the presence of polluted sludge within sediment } \\
\text { interstices ("sludge effect") }\end{array}$ & $\begin{array}{l}\text { Tubificinae with or without hair setae, Lophochaeta ignota, Tubifex tubifex, } \\
\text { Limnodrilus hoffmeisteri, Bothrioneurum sp., Lumbricillus spp }\end{array}$ \\
$\begin{array}{l}\text { FTRi: Includes oligochaete species which are moderately } \\
\text { tolerant to chemical pollutions }\end{array}$ & $\begin{array}{l}\text { Chaetogaster diastrophus, C. diaphanus, Nais communis, N. christinae, } \\
\text { N. barbata, N. pardalis, Slavina appendiculata }\end{array}$ \\
\hline
\end{tabular}

had been chosen so that discharged effluents were completely mixed with stream water across the stream channel during low flow conditions (Tlili et al., 2017). Sampling was performed on March 15 and 29, 2016 and on September 12 and 26, 2016. These WWTP had not been upgraded between the time when chemical measurements of water samples were performed (2013-2014) and when we collected samples for this study (2016). Both rivers flow through agricultural, industrial and urban areas upstream of the sampling sites (Burdon et al., 2016), which means that micropollutants were expected to be present even upstream of the WWTP. The distances between the sampling locations and the WWTP effluent input are: for Hochdorf $0.24 \mathrm{~km}$ (upstream) and $0.18 \mathrm{~km}$ (downstream); for Buttisholz $0.05 \mathrm{~km}$ (upstream) and $0.15 \mathrm{~km}$ (downstream).

\subsection{Oligochaete community analysis}

\subsubsection{Sampling and laboratory procedures}

Coarse surface sediments and the hyporheic zone were sampled separately. At each site, 3 subsamples (10-20 m apart) of coarse sediments and hyporheic zone were collected and subsequently combined.

Coarse sediment $(5-10 \mathrm{~cm}$ depth) was collected using a shovel, in a $5 \mathrm{~L}$ clean plastic bucket. The grain size of the coarse sediment samples was not measured, but was approximately similar between sites (mostly gravel, with sand and pebbles). Samples from the hyporheic zone (containing water, fine and sandy sediments) were collected in a $5 \mathrm{~L}$ clean plastic bucket by means of a probe inserted into coarse sediment to a depth of $20-30 \mathrm{~cm}$ and a Bou-Rouch pump (Bou $\&$ Rouch, 1967) fitted to the probe (Uwitec, Austria). The supernatant water was sieved in the field using a 0.16 or $0.20 \mathrm{~mm}$ mesh size sieve. The material retained in the sieve was transferred into the bucket. A volume of formaldehyde
$37 \%$ (Thermofisher, Switzerland) was then added to the buckets containing the samples for a final concentration of $4 \%$ formaldehyde.

At the laboratory, coarse sediment and hyporheos samples were sieved on a column of stainless steel sieves of 5 and $0.2 \mathrm{~mm}$ mesh sizes (Fisherbrand, Fisher Scientific, Switzerland). The material retained on the $0.2 \mathrm{~mm}$ mesh size sieve was transferred into a subsampling square box $(5 \times 5$ cells). The content of randomly selected cells was transferred into a petri dish and examined under a stereo microscope (Olympus, Model SZ51, Switzerland). Successive cells were examined until 100 identifiable oligochaetes were obtained. Oligochaete specimens were mounted on slides Oligochaete specimens were mounted on slides in a coating solution composed of lactic acid, glycerol and polyvinyl alcohol (mowiol 4-88) and identified to the lowest practical level (species if possible or genus or family) using a compound microscope (Olympus, Model BX43, Switzerland).

Generally, the number of specimens identified per site should be 100 . However, the FTR method can also be applied when the number of specimens obtained is smaller than 100 per site, which is common in hyporheic zone samples. If the number of specimens is $<20$, results of the community analysis should, however, be interpreted with caution.

\subsubsection{Functional traits}

Based on observations in the field (study of sites from pristine to highly altered, comparison of oligochaete community structure with physicochemical and hydrogeological data) and a literature study, Vivier (2006), Lafont and Vivier (2006) and Lafont et al. (2010a) classified oligochaete taxa of the porous matrix into 5 FTR categories (Tab. 1). FTR1 describes interactions between physical porosity of the coarse surface sediments and hyporheic zone and the hydraulic potentials. 


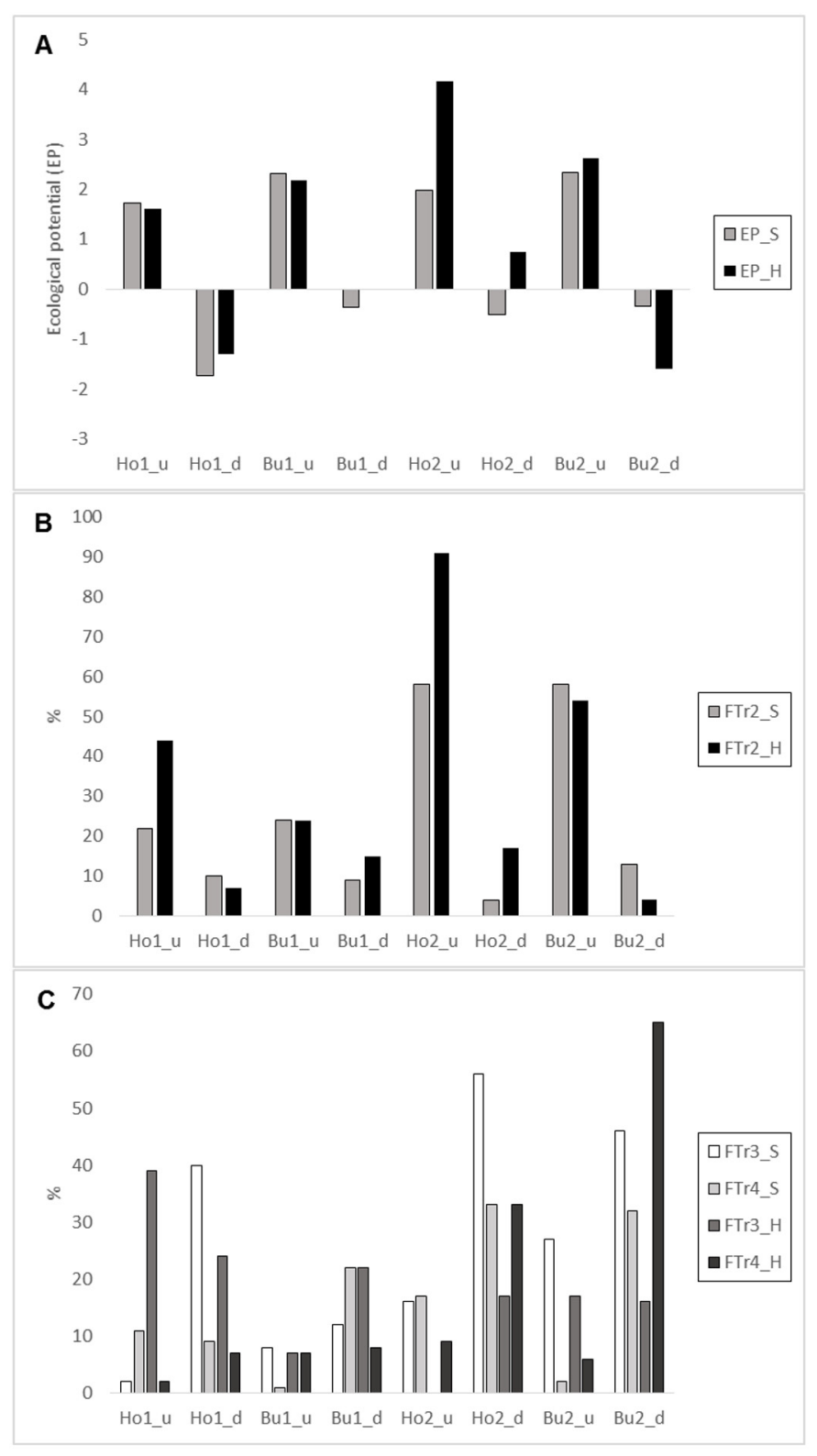

Fig. 1. Values of the ecological potential (EP) (A) and of the percentages of the functional traits 2, 3 and 4 of the sites situated upstream and downstream of the WWTP of Hochdorf and Buttisholz (B and C). EP_S=ecological potential in surface sediments; EP_H = ecological potential in the hyporheic zone; FTr2_S, FTr3_S, FTr4_S = functional traits 2, 3 and 4 in surface sediments; FTr2_H, FTr3_H, FTr4_H = functional traits 2, 3 and 4 in the hyporheic zone; Ho1_u=Hochdorf upstream in March; Ho1_d=Hochdorf downstream in March; $\mathrm{Ho}_{-} \mathrm{u}=$ Hochdorf upstream in September; Ho2_d=Hochdorf downstream in September Bu1_u=Buttisholz upstream in March; Bu1_d=Buttisholz downstream in March; Bu2_u=Buttisholz upstream in September; Bu2_d=Buttisholz downstream in September.

FTR2, FTRi and FTR3 comprise, respectively, intolerant, moderately tolerant and fully tolerant taxa to chemical pollution. FTR4 includes taxa, which indicate the presence of polluted sludge within the interstices of the porous matrix. These taxa are, in general, highly tolerant to pollution. FTR4 describes a highly altered functioning of the porous matrix. The percentages of these 5FTRs are used to assess, in the porous matrix, the effects of interactions between physical factors like the geomorphic context, the water fluxes (mainly the dynamics of water exchanges between surface water and groundwater), and the inputs of substances, such as nutrients and pollutants.

FTRs provide information on the direction of water fluxes between surface water and groundwater, particularly when the coarse surface sediments and hyporheic zone are sampled at the same location. The predominance of active exchange describer (AED) species (FTR1) in surface sediments indicates the exfiltration of groundwater. The intensity of water exchanges and exfiltration may be roughly assessed as follows: FTR $1<15 \%$ : low intensity; 16-30\%: moderate intensity; $31-50 \%$ : high intensity; $>50 \%$ : very high intensity. Conversely, the predominance in the hyporheic zone of species/taxa belonging to another FTR than FTR1 indicates the infiltration of surface waters. Surface water infiltration is low when the percentage of these species/taxa in the hyporheic zone is $<15 \%$, moderate $(16-30 \%)$, high $(31-50 \%)$, and very high $(>50 \%)$. AED species/taxa (FTR1) may belong to the FTR2 (intolerant species/taxa to pollution) or to the FTR3 (tolerant species/taxa to pollution). For example, Marionina argentea belongs to FTRs 1 and 2 and Pristina jenkinae to FTRs 1 and 3 (Tab. 1). It is thus possible to assess the state of pollution of groundwater by analyzing the composition of the AED species present in the surface sediments and hyporheic zone.

\subsubsection{Ecological potential}

The ecological potential (EP) describes the state of the functioning of each compartment of the porous matrix based on the percentages of FTRs (Lafont et al., 2010a). The EP is calculated using the following equation:

$$
\mathrm{EP}=\log _{2}[(\mathrm{FTR} 1+\mathrm{FTR} 2)+1] /[(\mathrm{FTR} 3+\mathrm{FTR} 4)+1]
$$

The EP corresponds to the ratio between FTRs considered as representative of a preserved functioning and that representative of an impaired functioning due to anthropogenic or non-anthropogenic causes. The EP allows to distinguish between various states of functioning, from preserved to highly altered. As the relation is converted into $\log _{2}$, negative values of the EP can be obtained. EP values $\geq 7$ characterize a well-preserved functioning of the system. Values between 2 and 7 correspond to a slightly to moderately altered functioning. In running waters of urbanized environments, values $\geq 7$ are rarely obtained, and the value of 2 becomes an objective of ecological potential corresponding to the lowest observed urbanization effects (Lafont et al., 2008). EP values below 2 depict states of major alterations. The causes of these alterations may be diverse and not only due to anthropogenic pressures. But when values are close to zero or negative, the main source of alteration is clearly associated with anthropogenic pressures. In addition, a low EP in both 
Table 2. Percentages of the functional traits (FTR1-4; FTRi) and ecological potentials (EP) obtained during the campaign of March and September (hypor= hyporheic zone; surf= coarse surface sediments).

\begin{tabular}{|c|c|c|c|c|c|c|c|c|c|c|c|c|c|c|c|c|}
\hline & \multicolumn{8}{|c|}{ Campaign of March } & \multicolumn{8}{|c|}{ Campaign of September } \\
\hline & \multicolumn{4}{|c|}{ Hochdorf } & \multicolumn{4}{|c|}{ Buttisholz } & \multicolumn{4}{|c|}{ Hochdorf } & \multicolumn{4}{|c|}{ Buttisholz } \\
\hline & \multicolumn{2}{|c|}{ Upstream } & \multicolumn{2}{|c|}{ Downstream } & \multicolumn{2}{|c|}{ Upstream } & \multicolumn{2}{|c|}{ Downstream } & \multicolumn{2}{|c|}{ Upstream } & \multicolumn{2}{|c|}{ Downstream } & \multicolumn{2}{|c|}{ Upstream } & \multicolumn{2}{|c|}{ Downstream } \\
\hline & Hypor & Surf & Hypor & Surf & Hypor & Surf & Hypor & Surf & Hypor & Surf & Hypor & Surf & Hypor & Surf & Hypor & Surf \\
\hline FTR1 & 84 & 23 & 5 & 4 & 43 & 25 & 15 & 17 & 88 & 76 & 67 & 58 & 94 & 94 & 22 & 48 \\
\hline FTR2 & 44 & 22 & 7 & 10 & 24 & 24 & 15 & 9 & 91 & 58 & 17 & 4 & 54 & 58 & 4 & 13 \\
\hline FTR3 & 39 & 2 & 24 & 40 & 7 & 8 & 22 & 12 & 0 & 16 & 17 & 56 & 17 & 27 & 16 & 46 \\
\hline FTR4 & 2 & 11 & 7 & 9 & 7 & 1 & 8 & 22 & 9 & 17 & 33 & 33 & 6 & 2 & 65 & 32 \\
\hline FTRi & 13 & 63 & 58 & 42 & 40 & 55 & 52 & 50 & 0 & 5 & 0 & 3 & 0 & 2 & 6 & 5 \\
\hline EP & 1.62 & 1.72 & -1.3 & -1.74 & 2.18 & 2.32 & 0 & -0.37 & 4.17 & 1.99 & 0.74 & -0.51 & 2.63 & 2.35 & -1.6 & -0.35 \\
\hline
\end{tabular}

the surface sediments and the hyporheic zone indicates pollution of surface water with surface water infiltration, or strong pollution of groundwater with groundwater exfiltration.

\section{Results}

A total of 36 oligochaete taxa belonging to the families Naididae (8 taxa of Tubificinae, 14 taxa of Naidinae, 3 species of Pristininae and one taxon of Rhyacodrilinae), Enchytraeidae (5 taxa) Lumbriculidae ( 3 taxa) and Lumbricidae ( 2 taxa) were found. All the functional traits were well represented (Tabs. 2 and 3 ).

At both sites (Hochdorf and Buttisholz), oligochaete communities indicated a better environmental quality upstream than downstream of the WWTP in both surface sediments and hyporheic zone. This was observed in both sampling campaigns. Percentages of sensitive taxa (FTR2) were higher and those of resistant taxa (FTR3 and FTR4) lower at upstream than at downstream locations (Fig. 1, Tabs. 2 and 3). The differences between upstream and downstream were more pronounced in September than in March. In September, a strong sludge-like effect (i.e. high percentages of FTR4) was observed in surface sediment and the hyporheic zone at the downstream sites. At the downstream location of Buttisholz and Hochdorfin in September, pollution-resistant AED taxa dominated communities in surface sediments, which suggested that contaminated groundwater entered the stream. As expected, the structure of oligochaete communities indicated moderate chemical pollution at upstream sites, likely due to non-point source contamination of the streams.

EP values were close to 2 or between 2 and 5 at the upstream locations, and negative, equal to 0 or between 0 and 1 at the downstream locations. Low EP values downstream were explained by both the strong dominance of pollution-resistant taxa and of taxa indicating infiltration of surface water into the hyporheic zone. The indication of surface water infiltration was more pronounced at downstream than at upstream sites, which can partially be explained by discharges of WWTP to the river. Results suggest that the capacity of self-purification was lower downstream than upstream of WWTP, and that the groundwater was vulnerable to pollution by surface water at the downstream sites.

\section{Discussion}

This study showed that the FTR method was able to detect the effects of pollutant inputs from the WWTP on environmental quality of the receiving streams. In addition, it provided valuable information on the capacity of the stream environment to self-purify and on the vulnerability of adjacent groundwater resources to pollution by surface water. Our results suggest that the FTR method allows the categorization of sites according to the degree of pollution, and thus can be used to detect local disturbances in impacted areas.

The FTR method is a valuable tool for biomonitoring programs as it can reveal alterations undetected by other biological indices. Burdon et al. (2016) studied macroinvertebrate communities upstream and downstream of 12 WWTP in Switzerland, among them Hochdorf and Buttisholz, the two WWTP studied here. These authors were unable to detect any impacts of the WWTP effluent using the IBCH macroinvertebrate index (OFEV, 2010), which is commonly used in monitoring programs throughout Switzerland. Similarly, the FTR method detected impacts of highway runoff on the receiving environment, while the French biomonitoring indices using diatoms, invertebrates and macrophytes were unable to detect such effects on the stream ecosystem (Lafont et al., 2010b).

Oligochaete abundance is generally considered to be an indicator of organic matter concentrations (Masson et al., 2010; Vivien et al., 2014). At the sampling locations of the study by Burdon et al. (2016), oligochaete abundances were significantly higher at sites located downstream of WWTP than at upstream sites. Quantifying oligochaete abundance alone, however, does not provide comprehensive information on the effects of WWTP effluents. An increase in oligochaete abundance is not necessarily associated with a degradation of biological quality, or vice versa. As in other community indices, it is important to consider if sensitive or tolerant taxa are present. An assessment of the impacts of WWTP effluent is only possible based on thorough knowledge of community 
Table 3. Oligochaete communities per sample during the campaigns of March and September. The values correspond to the numbers of specimens per taxon. The functional trait(s) FTR(s) of each taxon is (are) indicated in brackets (hypor=hyporheic zone; surf=coarse surface sediments).

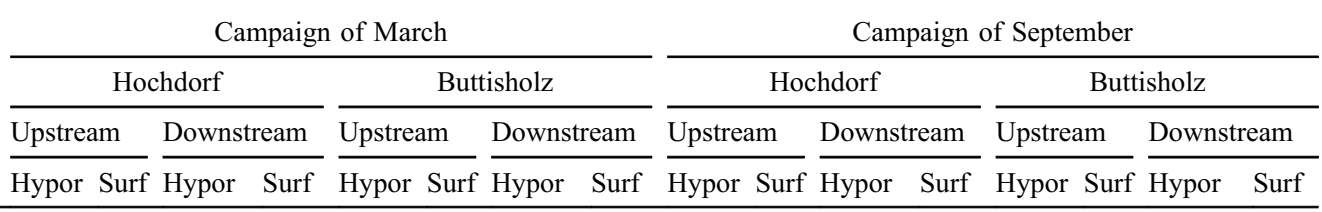

\section{Tubificinae (Naididae)}

Tubificinae without hair setae (FTR 4) 1

Limnodrilus hoffmeistreri (FTR 4)

Limnodrilus udekemianus (FTR 4)

Tubificinae with hair setae (FTR 4)

Potamothrix barbatus (FTR 4)

Aulodrilus pluriseta (FTR 4)

Lophochaeta ignota (FTR 4)

Tubifex tubifex (FTR4)

Naidinae (Naididae)

Amphichaeta leydigi (FTRi)

Chaetogaster diastrophus (FTRi)

Chaetogaster langi (FTRi)

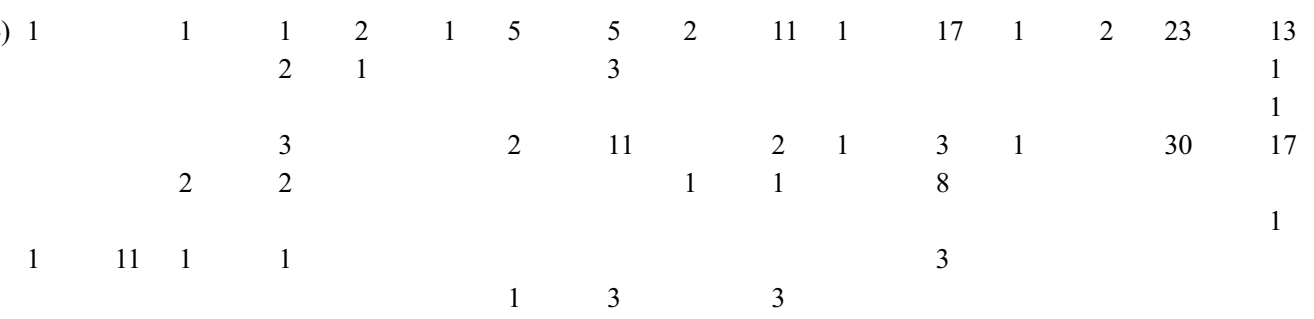

Chaetogaster parvus (FTR1 and 2)

Chaetogaster limnaei (FTRi)

Chaetogaster diaphanus (FTRi)

Nais alpina (FTR2)

Nais elinguis (FTR3)

Nais communis (FTRi)

Nais bretscheri (FTRi)

Nais pardalis (FTRi)

Nais variabilis (FTRi)

Nais christinae

Nais sp (FTRi)

\section{Pristininae (Naididae)}

Pristina aequiseta (FTR1 and 3)

Pristina jenkinae (FTR 1 and 3 )

Pristina longiseta (FTR1)

Rhyacodrilinae (Naididae)

Rhyacodrilinae sp (FTR1 and 2)

\section{Enchytraeidae}

Achaeta sp (FTR1 and 2)

Marionina argentea (FTR1 and 2)

Globulidrilus riparius (FTR 3)

Enchytraeus buchholzi (FTRi)

Cernosvitoviella sp. (FTR1 and 2)

\section{Lumbriculidae}

Lumbriculus variegatus (FTR i)

Stylodrilus heringianus (FTR 1)

Lumbriculidae g. sp (FTR1)

Lumbricidae

\begin{tabular}{|c|c|c|c|c|c|c|}
\hline \\
\hline 7 & 38 & 20 & 30 & 4 & 31 & 43 \\
\hline \multirow[t]{2}{*}{3} & 23 & 1 & 8 & 2 & 5 & 3 \\
\hline & 2 & 3 & 6 & 4 & 4 & 6 \\
\hline \multirow[t]{2}{*}{1} & & 13 & 41 & & 2 & 18 \\
\hline & & 6 & & & & 2 \\
\hline \multirow[t]{3}{*}{1} & 1 & 1 & 1 & 6 & 17 & 3 \\
\hline & & 1 & & 4 & 3 & 2 \\
\hline & & 1 & 4 & & & \\
\hline
\end{tabular}

\begin{tabular}{|c|c|c|c|c|c|}
\hline 26 & & 3 & & & \\
\hline \multicolumn{6}{|c|}{16} \\
\hline & & 4 & 2 & 7 & \\
\hline \multicolumn{6}{|c|}{2} \\
\hline & & & 1 & & \\
\hline 2 & 1 & 2 & 1 & 2 & \\
\hline 8 & & & 3 & & 3 \\
\hline 2 & & 1 & & & 4 \\
\hline 2 & & & & 2 & \\
\hline \multicolumn{6}{|c|}{1} \\
\hline \multirow[t]{2}{*}{2} & & 1 & 1 & & \\
\hline & & & 1 & & 1 \\
\hline
\end{tabular}

Lumbricidae sp (FTR2)

Eiseniella tetraedra (FTR 2)

composition and the traits of individual taxa, and identification of oligochaetes to the species or genus level is therefore necessary.

The implementation of the FTR method into biomonitoring programs requires solid expertise in oligochaete taxonomy, which may dissuade environment managers and consulting firms from using this methodology. It is generally preferred to use simpler and cheaper methods, even if they give incomplete information on the quality and the functioning of the ecosystem (Lafont, 2011; Lafont et al., 2012). However, we would like to emphasize that the identification of oligochaetes is no more difficult than the identification, for example, of 
diatoms, which are used routinely to monitor the water quality of streams. In addition, recent developments have shown that in the near future it will be possible, as part of biomonitoring programs, to genetically identify oligochaetes using high throughput sequencing and tagged primers, according to a methodology described in Shokralla et al. (2014).

Limiting the analysis of oligochaete communities to surface sediment only would significantly reduce the effort and cost per site. However, the inclusion of hyporheos samples allows a more reliable and complete assessment of the ecosystem functioning (Lafont and Vivier, 2006). The hyporheos tends to accumulate higher levels of pollutants than surface sediments; therefore, a focus on surface sediments alone would lead to an overestimation of environmental quality. Indeed, high flow episodes favor the decrease of pollution in surface sediments and the storage of pollutants in the hyporheic zone (due to infiltration of surface water), and surface sediments can be removed/transported during floods. In addition, the hyporheos is permanently saturated with water while surface sediments can periodically be dry (during low flow episodes). The FTR method can also be used specifically for the biomonitoring of hyporheos, as no other invertebrate monitoring methodology is yet available for that environmental compartment.

The FTR method is validated and ready to be applied in monitoring programs. A technical guideline for the methodology was provided by Vivier (2006), and the method is currently used by environmental consulting firms and research institutions in France and Switzerland. Nevertheless, the FTR method can and should be continuously improved as new data becomes available, for example, by adding information on functional traits, and by adapting the attribution of functional traits to each oligochaete species. For example, the FTRi was created specifically for species of the genus Chaetogaster and several species of the genus Nais, because these species did not fit any of the original FTR1-4. The ecological status of some taxa (for example Nais christinae and some species within the subfamily Rhyacodrilinae) remains uncertain, and more data are required to assign with certainty a functional trait(s) to these taxa.

The current prospects are to gain more experience and continue collecting data using the FTR method at sites with various degrees of chemical pollution and different dynamics of vertical hydrological exchanges, and up- and downstream of point sources of pollution. It is, for example, well suited for the study of Highly Modified Water Bodies (HMWB, sensu EU, 2000). The HMWB group encompasses all waterbodies whose physical context is altered by human activities to such a degree that a "good ecological status" cannot be reached, but "good ecological potential" exists (urban streams constitute a large part of HMWB). In the future, the application of the FTR method in such monitoring programs will be greatly facilitated by advances in the use of DNA barcodes for oligochaete species identification (Vivien et al., 2016; 2017; Lefrançois et al., 2018).

\section{References}

AFNOR. 2004. Qualité de l'eau. Détermination de l'indice biologique global normalisé (IBGN). Association française de normalisation (AFNOR), NF T90-350, France.
AFNOR. 2014. Qualité de l'eau-Guide pour l'étude des macrophytes aquatiques dans les cours d'eau. Association française de normalisation (AFNOR), NF EN 14184, France.

AFNOR. 2016a. Qualité de l'eau-Échantillonnage, traitement et analyse de diatomées benthiques en cours d'eau et canaux. Association française de normalisation (AFNOR), NF T 90-354, France.

AFNOR. 2016b. Qualité de l'eau-Échantillonnage, traitement et analyse des oligochètes dans les sédiments des eaux de surface continentales. Association française de normalisation (AFNOR), NF T 90-393, France.

Bou C, Rouch R. 1967. Un nouveau champ de recherches sur la faune aquatique souterraine. C R Acad Sci 265: 369-370.

Boulton AJ. 2000. River ecosystem health down under: Assessing ecological conditions in riverine groundwater zones in Australia. Ecosyst Health 6: 108-118.

Boulton AJ. 2007. Hyporheic rehabilitation in rivers: restoring vertical connectivity. Freshwater Biol 52: 632-650.

Boulton AJ, Hancock PJ. 2006. Rivers as groundwater-dependant ecosystems: A review of degrees of dependency, riverine processes and management implications. Aust J Bot 54: 133-144.

Breil P, Grimm N, Vervier P. 2007. Surface water-Ground water exchange processes and fluvial ecosystem function: An analysis of temporal and spatial scale dependency. In: Wood PJ, Hannah DM, Sadler PJ, eds. Hydroecology and ecohydrology: Past, present and future. New York: John Wiley and Sons Ltd, pp. 93-111.

Brunke M, Gonser T. 1997. The ecological significance of exchange processes between rivers and groundwater. Freshwater Biol 37: $1-33$.

Burdon FJ, Reyes M, Alder AC, Joss A, Ort C, Räsänen K, Jokela J, Eggen RIL, Stamm C. 2016. Environmental context and magnitude of disturbance influence trait-mediated community responses to wastewater in streams. Ecol Evol 6: 3923-3939. https://doi.org/ 10.1002/ece3.2165.

EU. 2000. Water Framework Directive, Directive 2000/60/CE of the European Parliament and of the Council of 23 October 2000, establishing a framework for community action in the field of Water Policy.

Hancock PJ. 2002. Human impacts on the stream-groundwater exchange zone. Environ Manage 29: 763-781.

Hancock PJ, Boulton AJ. 2005. Aquifers and hyporheic zones: Towards an ecological understanding of groundwater. Hydrogeol $J$ 13: $98-111$.

Hynes HBN. 1983. Groundwater and stream ecology. Hydrobiologia 100: 93-99.

Jones JB, Mulholland PJ. 2000. Streams and ground waters. San Diego: Academic Press, $425 \mathrm{p}$.

Lafont M. 2001. A conceptual approach to the biomonitoring of freshwater: The ecological ambience system. J Limnol 60: 17-24.

Lafont M. 2011. Towards ecohydrological approach of biomonitoring in running waters. Ecohydrol Hydrobiol 11: 9-22.

Lafont M, Vivier A. 2006. Oligochaete assemblages in the hyporheic zone and coarse surface sediments: Their importance for understanding of ecological functioning of water courses. Hydrobiologia 564: 171-181.

Lafont M, Vivier A, Nogueira S, Namour P, Breil P. 2006. Surface and hyporheic Oligochaete assemblages in a French suburban stream. Hydrobiologia 564: 183-193.

Lafont M, Marsalek J, Breil P. 2008. Urban aquatic habitat characteristics and functioning. In: Wagner I, Marsalek J, Breil $\mathrm{P}$, eds. Aquatic habitats in integrated urban water management, Chapter 2, Urban water Series-UNESCO-IHP. The Netherlands: Taylor and Francis Group, pp.9-24. 
Lafont M, Jézéquel C, Vivier A, Breil P, Schmitt L, Bernoud S. 2010a. Refinement of biomonitoring of urban water courses by combining descriptive and ecohydrological approaches. Ecohydrol Hydrobiol 10: 3-11.

Lafont M, Prompt P, Bernoud S, Bourgeot F, Auboin J, Laluc M, Camps P, Jézéquel C, Lebrun P. 2010b. Incidence écologique des rejets polluants sur les cours d'eau dans un contexte de paysages routiers imperméabilisés, Cemagref ed. Rapport GREBE/BURGEAP/Cemagref/ASF. Lyon: Cemagref, $26 \mathrm{p}$.

Lafont M, Tixier G, Marsalek J, Jézéquel C, Breil P, Schmitt L. 2012. From research to operational biomonitoring of freshwaters: A suggested conceptual framework and practical solutions. Ecohydrol Hydrobiol 12: 9-20.

Lefrançois E, Apothéloz-Perret-Gentil L, Blancher P, Botreau S, Chardon C, Crepin L, Cordier T, Cordonier A, Domaizon I, Ferrari BJD, Guéguen J, Hustache J-C., Jacas L, Jacquet S, Lacroix S, Mazenq A-L., Pawlowska A, Perney P, Pawlowski J, Rimet F, Rubin J-F., Trevisan D, Vivien R, Bouchez A. 2018. Development and implementation of eco-genomic tools for aquatic ecosystem biomonitoring: The SYNAQUA French-Swiss program. Environ Sci Pollut Res 25: 33858-33866.

Malard F, Uehlinger U, Zah R, Tockner K. 2006. Flood-pulse and riverscape dynamics in a braided glacial river. Ecology 87: 704-716.

Masson M, Desrosiers M, Pinel-Alloul B, Martel L. 2010. Relating macroinvertebrate community structure to environmental characteristics and sediment contamination at the scale of the St Lawrence river. Hydrobiologia 647: 35-50.

Munz NA, Burdon FJ, De Zwart D, Junghans M, Melo L, Reyes M, Schönenberger U, Singer HP, Spycher B, Hollender J, Stamm C. 2017. Pesticides drive risk of micropollutants in wastewaterimpacted streams during low flow conditions. Water Res 110: 366377. http://doi.org/10.1016/j.watres.2016.11.001.

OFEV. 2007. Méthodes d'analyse et d'appréciation des cours d'eau en Suisse. Diatomées-Niveau R. Berne, Suisse: Office fédéral de l'environnement.

OFEV. 2010. Méthodes d'analyse et d'appréciation des cours d'eau en Suisse. Macrozoobenthos-Niveau R. Berne, Suisse: Office fédéral de l'environnement.
Schmitt L, Lafont M, Trémolières M, Jézéquel C, Vivier A, Breil P, Namour P, Valin K, Valette L. 2011. Use hydro-geomorphological typologies in functional ecology: Preliminary results results in contrasted hydrosystems. Phys Che Earth 36: 539-548.

Schmitt L, Grosprêtre L, Breil P, Namour P, Lafont M, Delile H, Eschbach D, Jacob-Rousseau N, Cournoyer B. 2016. L'hydromorphologie, une dimension-clé pour l'étude interdisciplinaire des petits hydrosystèmes périurbains (bassin de l'Yzeron, France). Bull Soc géo L 67: 161-179.

Shokralla S, Gibson JF, Nikbakht H, Janzen DH, Hallwachs W, Hajibabaei M. 2014. Next-generation DNA barcoding: using nextgeneration sequencing to enhance and accelerate DNA barcode capture from single specimens. Mol Ecol Resour 14: 892-901. DOI: 10.1111/1755-0998.12236.

Tlili A, Hollender J, Kienle C, Behra R. 2017. Micropollutantinduced tolerance of in situ periphyton: establishing causality in wastewater-impacted streams. Water Res 111: 185-194. https://doi. org/10.1016/j.watres.2017.01.016.

Vivier A. 2006. Effets écologiques de rejets urbains de temps de pluie sur deux cours d'eau périurbains de l'Ouest Lyonnais et un ruisseau phréatique en plaine d'Alsace. Thesis, L.P. France: University Strasbourg, $208 \mathrm{p}$.

Vivien R, Tixier G, Lafont M. 2014. Use of oligochaete communities for assessing the quality of sediments in watercourses of the Geneva area and Artois-Picardie basin (France): Proposition of heavy metal toxicity thresholds. Ecohydrol Hydrobiol 14: 142-151.

Vivien R, Lafont M, Ferrari JD. 2015. Utilisation des communautés d'oligochètes pour l'évaluation de la qualité biologique et du fonctionnement des cours d'eau: un bilan à partir de données genevoises (Suisse). Arch Sci 68: 105-116.

Vivien R, Lejzerowicz F, Pawlowski J. 2016. Next-generation sequencing of aquatic oligochaetes: Comparison of experimental communities. PLoS ONE 11(2): e0148644.

Vivien R, Holzmann M, Werner I, Pawlowski J, Lafont M, Ferrari BJD. 2017. Cytochrome c oxidase barcodes for aquatic oligochaete identification: Development of a Swiss reference database. PeerJ 5: e4122.

Cite this article as: Vivien R, Lafont M, Werner I, Laluc M, Ferrari BJD. 2019. Assessment of the effects of wastewater treatment plant effluents on receiving streams using oligochaete communities of the porous matrix. Knowl. Manag. Aquat. Ecosyst., $420,18$. 